\title{
Lung Hilum Neoplasm
}

National Cancer Institute

\section{Source}

National Cancer Institute. Lung Hilum Neoplasm. NCI Thesaurus. Code C5671.

A benign or malignant neoplasm that arises from the hilar region of the lung. 